\title{
The Radical Character of Art and the Pedagogical and Political Value of the "Sublime" in Adorno's Aesthetic Theory
}

\author{
Alexandros Theodoridis \\ Democritus University of Thrace
}

\begin{abstract}
The critical nature of artwork is owed, according to Adorno, to the fact that it opposes its assimilation by reason and that it does not yield to the imposition of its established principles. This character which Heidegger, too, through a paradoxical convergence with Adorno, and in opposition to Lukács, recognizes as its ontological component, permits the work of art to represent a force of resistance to dominance in general, in the prospect of the salvation of a humanized society. As such, it makes possible the radical rejection of political and, pertinent to it, pedagogical activity, when converted into primarily authoritiarian activity. Such a responsibility does art assume, according to Adorno, when it represents a spirituality, which is embodied in exemplary fashion both in the work of art itself, making the experience of the sublime possible, and in the aesthetic of the sublime, which is concentrated intensively on whatever remains unapproachable through concepts. In this way, we could say that the aesthetic of the sublime is converted into "first philosophy," in the sense that it provides the rule for every theoretical approach. Concurring with this reading of Adorno, we consider how the sublime, as shown in the context of his aesthetic theory, is governed, furthermore, by a paideutic principle of exceptional significance, which we must necessarily activate through aesthetic education, so that western man may understand that he must uproot himself from the nihilistic social context in which he lives, rupturing the delusion of his omnipotence. In a world governed by a permanent crisis of democracy in public and private life, since the weakening of political imagination unites with the retreat from political ethos and an generalization of the unprecedented will for dominance, we consider this aesthetic theory to be exceptionally essential and useful to us both as pedagogical theory and as political theory, since it allows us to understand that the experience of the sublime through art is in opposition to this condition of destruction, and indeed represents the ideal of justice.
\end{abstract}

Keywords: art, sublime, paideutic value, nihilism, opposition to destruction

If we have the ability not only to understand the world but to imagine it otherwise, according to Adorno, we owe to art. Indeed, we cannot be reserved on that score if we consider that ontologically art is a window on Chaos, as Castoriadis has shown; a way to present and give shape to the Abyss; that with which every understanding begins and ends. For exactly this reason, the work of art has, for Castoriadis, a poetic substance through which a world entirely its own is born and, simultaneously, the being is presented, and the Abyss is presented, without symbolism and without allegory. ${ }^{1}$

Alexandros Theodoridis, Ph.D., assistant professor, Department of Education Sciences in Early Childhood, Democritus University of Thrace, Greece; main research field: Philosophical Anthropology, Problems of Philosophy in Education Sciences, Philosophy of Education and Education Policy, Political Philosophy, Political and Moral Education, Intercultural Ethics and Environmental Ethics. 
For something like this to be possible, of course, art, as Adorno stresses, must have a strong social footing; so, it must be self-recognized beyond the logic of aestheticism, of which the clearest and most discernible development is the theory of art on art, in the context of which the idea of a full separation between art and society, ethics, and even life itself developed. ${ }^{2}$ Adorno, indeed, will insist that in the context of this condition we must always place the great duty of art: its unhooking from the delusion of the reconciliation of contradictions, considered as a beautiful entirety. Furthermore, art as an event should represent the artist's protest against reality. ${ }^{3}$ How, then, can art, while it avoids the canard of aestheticism, show the reconciliation of contradictions to be a delusion and be constituted as representing the artist's protest against what exists?

The work of art, according to Adorno, can only have an ever-critical character, exactly because it is not assimilated by speech and does not submit to its established values. This character, it follows, allows it to set itself apart from each reality and accords it the power of resistance to dominant forces in general. As such, it makes it capable of radically refusing political activity as well, when such activity would undermine its own self instrumentalized, when, that is to say, it becomes mainly authoritative activity. ${ }^{4}$ Only the spirituality of art can, for Adorno, undertake such a responsibility. ${ }^{5}$ This spirituality finds its exemplary embodiment as much in the work of art itself, which makes the experience of the sublime possible, as in the aesthetic of the sublime, due to its insistent concentration on whichever of its meanings remains unapproachable. ${ }^{6}$ Accordingly, we could say that the aesthetics of the sublime transform into "first philosophy," in the sense that they provide the rule for every theoretical attempt. ${ }^{7}$

With this reading of Adorno as a starting point, we consider that the sublime, as it is displayed in the context of the philosopher's aesthetic theory, is governed by, in addition, a paideutic value of great significance which we must activate at all costs with the prospect of a confrontation of the generalization of the spirit of nihilism, which now consumes the western world, in public as in private life. In a world which continues to commercialize everything and generalize volition for dominance in an unprecedented way, ${ }^{8}$ an aesthetic theory which allows us to understand how the experience of the sublime through art is set in opposition to this condition of destruction and, indeed, representing the ideal of justice; we consider how this theory is for us especially necessary, useful both as a pedagogical theory and as a political one.

That which Adorno considers the duty of art, that it may save a humanized society as well as its own self, Heidegger recognizes as its ontological characteristic, as what makes art and the work of art to be. ${ }^{9}$ And if we cannot see Heidegger arrayed alongside Adorno and Merleau-Ponty in the activation of a program that Benjamin had proclaimed "the politicization of art," which the dominant character of politics may be reflected back as repugnant, ${ }^{11}$ surely we ought to see him arrayed with them in the attempt for the salvation of a philosophical aesthetic, in the context of which it becomes clear that aesthetic figurations are broken open onto the ontological horizon, but also mediated by historical understandings and social issues; ${ }^{12}$ potentially even by utopian expectations. ${ }^{13}$ Such a philosophical aesthetic is not governed only by a genuine theoretical strength but also by a practical interest as much political as pedagogical, which is registered in the prospect of the liberation of man. ${ }^{14}$

The value, as a result, as much of Heidegger's thought as of Adorno's on this issue, lies in the fact that, through a paradoxical convergence and in contradiction with Lukács, ${ }^{15}$ they defined what dignifies art with its radical character, which is none other than the fact that art makes possible the emergence of a world which does not function in a contemporary technical manner; in other words, it is not subject to the technoscientific rationality which oppresses the humane at all levels of its articulation and which both thinkers recognize as a 
pure threat to the contemporary world. ${ }^{16}$ The "Logical-Technical-Authoritative" complex is read by both as a symptom of a general alteration in the structures of thinking, analogous to the technical rules, a fact that its part refers to the dominance of the technical over nature, and the subjugation of man which is connected with it, as its actual cause. This threat, which takes form and substance both as the enforcement of political compulsion as logical compulsion, and as the demand for the eternal recycling of it, can be confronted, with all values retained, by a radical art, able to preserve the freedom of self-determination, as well as the ability for a substantive change of the actual into the eternal. And this only an art oriented toward the absolute, a sublime art, can achieve.

In Adorno's more Hegelian language, it is exactly the power of the negative and the designation of the power of the possible versus the extant. In Heidegger, it is expressed, as we have said, through the power of a work of art, to be able to change the world, so that history can restart with it. ${ }^{17}$ Since art opens up a world which leads into the open historicity of existence, Heidegger shows us that he places in doubt the world in which it is located. He removes the existential, conceptual, and representational footing and, in this way, undermines not only the social and political articulations of the world in which we exist, but also places into doubt its very formation as a social and political being. As such, it is abundantly clear that the radical nature of art lies in that it makes possible for the being to be opened up to a future which is not authoritative-dominant. And also, as such, art becomes a negative art. Let us insist here that art, denied in this way, is not recalcitrant but incredulous; it wishes, in other words, to be a criticism and it attempts various methods of coordination with a vision of the future that becomes an aspiration. In no way, then, it is what displays the aesthetic of the postmodern. ${ }^{18}$

Lyotard will stress the importance of the sublime; however, in contrast to Adorno and Heidegger, he will see it as connecting with the desire as a longing for the impossible, in the environment of the postmodern "megalopolis," in other words, in the place where nihilism emerges. This desire, as a longing not for the possible but for the impossible, underlines the weakness of will to shape the material, a thing which nonetheless occurred in the environment of the polis, the town, and the metropolis, and confirmed the hegemony of each over time. In the environment of the contemporary megalopolis, something of the sort happens because its residents are weak-willed and apathetic. The only thing they want is nothingness, which takes on the dimensions that the absolute, beyond limits, had throughout history. Here there is not, according to Lyotard, within and without, center and exurban, other and same, since nothing can fail to be at once both other and not other. $^{19}$

In such a context, and in contrast to the philosophers of modernism, Lyotard considers that the philosopher has nothing to do beyond expressing emotions born in him by the impossibility of philosophy as quest for the truth, the good, and the beautiful. Thus, the desire for the possible as the desire of fulfillment (conquest over the fine, the just, the truth, the sublime, the terrible, or the unutterable) is cancelled out and joined to the impossible. However, although the intellectual burden of Lyotard of Economie libidinale and L'inhumain is not identified with the intent to shape shapeable material, and this because it revolves around unshaped material, which expresses the nihilism of the "megalopolis," connected with the intent to generalize an aestheticization as the counterweight to the generalization of commercialization, which postmodern society appears to worship. ${ }^{21}$

Let us consider things in their proper order. Focusing our attention on Adorno's aesthetic philosophy, we must state, at the outset, that he recognizes art as negative, not only because it can rescue truth, as we have said, 
but also because it can rescue happiness. Happiness, here, is counted with a material significance, a principle which binds all the Frankfurt School thinkers. ${ }^{22}$ It is precisely the irreducible corporeality, the self-worth of the natural, which only the aesthetic can rescue, in the context of a world which it controls via enforcement.

Violating exactly this self-reliance of the material, Hegel, in combination with the violation of the unique mediations of form, is led, according to Adorno, to the formulation of a "raw" teaching on the content of the work of art, despite its dialectical character. ${ }^{23}$ Hegel integrates, as we know, the content of art into the general motion of the idea, of which the conception is abstract and in substance theological. ${ }^{24}$

It is true that Hegel's asceticism and idealism, expressed violently against the materiality of the thing and preventing him from understanding the aesthetic dimension of the content, appear mainly when he negotiated the relationship between nature and art. This negotiation interests us in the context of the discussion on the sublime, since here it is plain to see Hegel's choice to reduce nature in relation to art, with regard to the fine which both represent. In such a context, Hegel ascribes to nature only one privilege: to participate in a "more sublime" motion of the idea.

Faithfully following a tradition which uses the idea to subjugate the material world, a tradition that begins as early as Plato, if not earlier, Hegel writes in the introduction to his Aesthetics:

But we may assert against this view, even at this stage, that the beauty of art is higher than nature. The beauty of art is beauty born of the spirit and born again, and the higher the spirit and its productions stand above nature and its phenomena, the higher too is the beauty of art above that of nature. Indeed, considered formally [i.e., no matter what it says], even a useless notion that enters a man's head is higher than any product of nature, because in such a notion spirituality and freedom are always present... Now, in this its freedom alone is fine art truly art, and it only fulfils its supreme task when it has placed itself in the same sphere as religion and philosophy, and when it is simply one way of bringing to our minds and expressing the Divine, the deepest interests of mankind, and the most comprehensive truths of the spirit... What is thus displayed is the depth of a suprasensuous world which thought pierces and sets up at first as a beyond in contrast with immediate consciousness and present feeling; it is the freedom of intellectual reflection which rescues itself from the here and now, called sensuous reality and finitude. But this breach, to which the spirit proceeds, is also able to heal. It generates out of itself works of fine art as the first reconciling middle term between pure thought and what is merely external, sensuous, and transient, between nature and finite reality and the infinite freedom of conceptual thinking. ${ }^{25}(2 ; 7 ; 8)$

Surely here Hegel commits the error of distinguishing liberty against nature. He goes so far as to place art at a higher level even than the Absolute Spirit. ${ }^{26}$ What characterizes it is considered by him the unique clash between appearance and substance.

In relation, now, to the form of art, Hegel will see how one of its disadvantageous sides is, even in cases where art is in the service of serious aims that the means which it uses are an illusion. He credits, though, that the superior mission of art is to subjugate the anarchical multiplicity of appearance to the idealized form, which is considered to be the expressed form of its spiritual substance. ${ }^{27}$ Hegel will say,

Now art and works of art, by springing from and being created by the spirit, are themselves of a spiritual kind, even if their presentation assumes an appearance of sensuousness and pervades the sensuous with the spirit. In this respect, art already lies nearer to the spirit and its thinking than purely external spiritless nature does. In the products of art, the spirit has to do solely with its own. And even if works of art are not thought or the Concept, but a development of the Concept out of itself, a shift of the Concept from its own ground to that of sense, still the power of the thinking spirit lies in being able not only to grasp itself in its proper form as thinking, but to know itself again just as much when it has surrendered its proper form to feeling and sense, to comprehend itself in its opposite, because it changes into thoughts what has been estranged and so

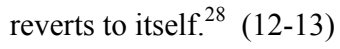


This Hegelian conception cannot help but presuppose an internalization of the cultural rules and to lead, in practice, to a repulsion of the material component of art. Pertinent to this, however, it requires in addition the reduction of the element of pleasure which is of necessity woven together with it, so as to make possible its disciplined inclusion in an ethical-paideutic ideal which is encouraged by a program of urban education. There is no doubt that this ideal stems from the Schillerian On the Aesthetic Education of Man, which Hegel clearly recognizes. ${ }^{29}$ At the prospect, indeed, of a subjective function of art, Hegel will arrive through asceticism to deny every departation that desire places, to recognize it as the cleansing of the passions.

Art by means of its representations, while remaining within the sensuous sphere, liberates man at the same time from the power of sensuousness. Of course we may often hear favorite phraseology about man's duty to remain in immediate unity with nature; but such unity, in its abstraction, is purely and simply rudeness and ferocity, and by dissolving this unity for man, art lifts him with gentle hands out of and above imprisonment in nature. $^{30}$

Despite the fact that Hegel wishes, according to his dialectic intent, to understand the historicity of art, surpassing the idea of beauty to which remains attached every traditional aesthetic, this stance toward art renders the idea, according to Adorno, ultimately unsurpassable and allows it to ridicule the historicity of his intentions. And as such, rightly Adorno alleges that aesthetic philosophy is not possible in our era. And this, in addition, is not only because the reality of developed capitalism has rendered impossible every autonomy of the aesthetic sphere, neutralizing its products, as they are traded on the market, which of course is true, but, mainly, because such a reality revealed retrospectively the falsehood which was hidden equally in the construction of the aesthetic as an independent sphere within urban society, fortified behind the supposed autonomy of artistic form, ${ }^{31}$ and in the reliance of art on the "sublime" imagined content, unlinked in large part from form. And here there is no doubt that this is none other than the market itself. ${ }^{32}$

Adorno, nevertheless, will defend one of Hegel's points that he conceives of the aesthetic sphere as the primary place of composition; in other words, where those things which our consciousness reads as differentiated, appear undifferentiated: form and content, subject and object, spirit and sensuality, teaching and entertainment, etc. When Hegel claims that the meaning of beauty, seen philosophically, is necessary to contain, mediated, both aforementioned extremes through the wedding of metaphysical generality with the attribution of actual partiality, since only thus can we conceive the truth in and through itself, resettle a demand for truth in the region of aesthetics. ${ }^{33}$ And Adorno cannot avoid being attracted by the type of dialectic mediation which Hegel recommends, when he writes "a duty of philosophy will be to resolve these contradictions, to demonstrate that neither the one with its deletion, nor the other with its one-sidedness contain truth, but both are what negate its self; truth is located only in reconciliation and mediation" (348-53). ${ }^{34}$

Of course this conception of the aesthetic sphere has its origins in Kant, to whom Hegel will ascribe the concept that the reconciliation about which he speaks becomes possible only subjectively and not as something in and through itself true and real. Inclining towards Hegel, Adorno will show what through the significance of beauty surpasses simple aesthetic judgment. Aesthetics, he stresses, must move towards truth. Otherwise it becomes gastronomy. ${ }^{35}$

The duty of connection with the demand for truth takes on an "objective aesthetic," recognizing aestheticism as a form of reification, cooperating even where it does not wish to with its apparent opposite, that is, the delivering of the artwork to the generalized system of exchange on the market, he interprets the absolute autonomy of taste as pure caprice. This autonomy is symbolized in the final analysis by the fetishism of 
merchandise, the trading price of "beauty." Aesthetics, then, which Adorno defends, reaches Hegel through Lukács. This is because, despite the great differentiation between them in individual particulars, Adorno, as much as the philosophers of the School in general, recognizes the Lukácsian concept of artwork as a formic entirety, which reflects historical relationships crystallized in worldviews. ${ }^{36}$ Through this prism, art for the School is "the hieroglyphic of history" which renders the aesthetic form witness of the true. And this, let us stress, is not to the degree that it participates in a "more sublime" motion of the idea as Hegel wants, but because it roots into the depths of social reality. Adorno's position that no one can be worthy of a Beethoven symphony, if he is not in a position to understand the so-called musical events in it and if he does not hear in it the musical reverberations of the French Revolution, is well known. ${ }^{37}$

Adorno will not forget his indebtedness to Kant, however, because he admits the perplexity between aesthetic objectivity and fine aesthetic judgment, and preserves a hint of the impulsive substratum of every aesthetic through the experience of aesthetic enjoyment. ${ }^{38}$ Adorno sees this element as resting in the unique artistic form, which essentially bears witness to the resistance of the material to the "spiritual" impressions that it will suffer during artistic formation. Thus, aesthetic enjoyment is the place of memory of the pre-aesthetic game, with its particular materials, and becomes a symbol of the entire natural substratum which dwells at the base of art. For exactly this reason, the strained relationship between the mimetic and the constructed element, a dramatic metaphor for the relationship of nature to art, becomes the domain upon which Adorno will reconstitute the dialectic of the aesthetic. ${ }^{39}$ And in this domain, beauty in nature cannot but weave together with the ugly, opposite the category of which aesthetics generally feels uncomfortable. Nevertheless, the category of the ugly is essentially the answer to the question on the origin of beauty and reflects horror at natural expressions. ${ }^{40}$ This beauty in nature, more dialectical than the aesthetically beautiful, since it is always accompanied by a hint of horror, reminds us, according to Adorno, of the cradle from which art ever is drawn and from which, at the same time, it ever flees. The significance of beauty in nature scratches a wound and one need not reach to consider that together with it, violence also, which is the work of art as a construction, commits against nature; against a nature which civilization from early on tried to subordinate with sense and tool. ${ }^{41}$ On such a horizon, the clarification of the relationships of art with the technical and with language becomes a primary concern of Adorno's aesthetic theory.

Exactly as Heidegger did, Adorno will connect art and the technical, which primarily represents the violent rational authority of man over nature. ${ }^{42}$ Nevertheless, he considers that this connection is also salvatory for the technical, since it establishes the hope of a peaceable technology which presages the re-reconciliation with nature, the redemption of culture for the atrocities that it has committed against it. "Aesthetic rationality," he writes, "wishes to atone for the damage which rationality in the service of dominance over nature has caused to the outer world" (34; 91-93). ${ }^{43}$

In this context, Adorno will attempt to redefine the relationship of art to language but, pertinently, also with the subject and society. All works of art, he will stress, are language, and are texts. And they are language because they participate in conceptual structure. Nevertheless, this is what is significant; this language of theirs is not the monosemantic, defined conceptual language, which is responsible for every intent to dominate nature; it is the language of primeval polysemy. ${ }^{44} \mathrm{He}$ who stands opposite a work of art must proceed to the space between the natural and the civilized, so that the language of art can be heard. As long as art is governed by the strange condition to say something or not to say it, we must accept that what it says (its mimetic element) is in opposition to the speaking. ${ }^{45}$ In such a context, however, the linguistic element and the corresponding technical 
element in art seem to denounce through their particular position, to the same extent that they participate in them, the generalized will of domination that resides in the conceptual language and in the technical. Of course, at the same time, they look to the unutterable, as yet unexpressed place. "Works of art, especially great ones, await their interpretation," writes Adorno, "these works cannot arrive where they objectively tend. The band of indeterminacy that lies between the unattainable and the achieved constitutes exactly their enigma" (1979). ${ }^{46}$

The unhooking of art from conceptual language will end up, however, equally creatively in the understanding of the problem of subjective expression in art. Adorno, while he in no way doubts that a creator's intent is always carved upon the work of art, considers that it is an error to identify what the artwork ultimately is with the experiential subject of the creator. Into such an error, it is true that the psychoanalytical attempt of art analysis did fall, which the philosopher, in this particular case, faults with amateurism. ${ }^{47}$ To explain everything in art by the unconscious and not to consider that in artistic production impulses are simply stimuli and materials, is, for Adorno, a grave error. For such an "inelegance," surely the worship of the principle of reality by psychoanalysis is to blame, since every disobedience to it is interpreted as a flight. In this way, however, the adaptation to reality is appointed to the supreme good. Quite rightly, then, Adorno will note that, if art had psychoanalytical roots, these would be none other than the roots of fantasy through the imagination of omnipotence. $^{48}$

Through this, however, the desire of a better world arises. ${ }^{49}$ Thus, the ego of the artist is open to a non-ego. This takes place either on the level of the imaginary which is governed by the impulsive impetus and does not yet know the tautological claims that the copies of itself create, or on the level of the symbolic, which is open to what the German philosopher calls "the law of form" and gives form and substance to social imaginary meanings, which through the act of production create and recreate collective subjects, recognizable in any case in other expressions of social practice as well. ${ }^{50}$

At this point, we can also note, at the base of the strained relationship that sets the philosopher between art and society, that the subject of a work of art is neither the observer nor the creator nor the absolute spirit, but rather the spirit that is connected with the thing; it is pre-shaped and this in its turn mediates with the object. ${ }^{51}$ So, we see that Adorno never compromises on the idea of an omnipotent subject, which can, through signifying forms, conceive of an object (nature or society) and which by definition is identified with the gnostic goals of the subject.

This relationship of the spirit to the thing must refer to the mimetic principle of art, onto which and under terms contrary to which the socio-historical determinations related to the open question, either whether the fallible "I," the speaking "I," is the same in all types of art, or whether through artwork, even so-called individual ones, a "we" speaks, rather than an "I"-indeed more clearly by as much as it is less externally adapted to a "we" and its idiom - are subsequently articulated. ${ }^{52}$ Nevertheless, Adorno will stress that what makes art real is the schism, the irreconciliation between itself and that to which it speaks through itself. But its truth is won, ultimately, when it pulls together what had been split apart and only thus defines it as irreconcilable. The oddity, of course, is that it must bear witness to the irreconcilable and to tend despite that to reconcile it. This ability rests only with non-reflective language. Only in this procedure is its "I-we" made particular. ${ }^{53}$

It is very interesting to see that Heidegger will similarly consider language as a place where the speaking of man confronts the $\log o s$ as a battle. ${ }^{54}$ This $\log o s$ is the very being which calls upon beings to show themselves in their conflicts, at their differences, and at the same time gathers them together through the 
revealed, through this juxtaposition, unity of their existence. ${ }^{55}$ This gathering has the same meaning as the organization of thought. The archegonial unity of our being is none other than archegonial poetry, within which the word is the being itself; it is the logos which refers to the revealing speech of he who is. This meaning has a Heideggerian position that what speaks first of all is not man but language, which, by speaking, opens for us the truth of being. ${ }^{56}$

Every art, then, since it allows the truth to appear, is substantively poetry. The language of poetry is what first gave name to beings, making them appear. But such a language, Heidegger will stress, is not that of sharing; that is, in other words, what allows us to speak to one another and to communicate. This language does not transmit the visible and the hidden as thus understood. It shows, as we said, beings as beings for the first time. "Wherever there is no language, for example inside the being of a rock, a plant, and an animal," he writes: "There cannot be either the openness of beings or, as a result, the openness of non-beings and of the void." The poetry in pre-semiological language speaks the non-concealment of beings. Such a speaking "prepares the spoken, and brings the unspoken into the world like such a one... Language itself is in substance, poetry... But the substance of poetry is the establishment of the truth" $(123-5) .^{57}$

Heidegger, after the so-called "turn" (Kehre), will make clear through a noble effort that poetry preserves the first and foremost function of language, since it brings to light what is hidden behind common words and their experiential daily representations, exactly why language has an expressive element aside from its communicative one. In this element is preserved the archegonial and mimetic quality of linguistic execution, before the language becomes instrumentalized in order to meet the needs of a technically oriented, tyrannical culture. ${ }^{58}$ Such a language is far removed from every meaning of domination.

We consider that through this same prism Adorno claims that there is a contradiction between art and society and that only the fact that art exists entails the exercise of criticism on society. Art, defying society, can be kept alive. For art to be able to make an impact on society, it must flee from it. ${ }^{59}$ Only then can it become radical and lead to a rupture, through its merciless conflict with the possible, what does not yet exist, the utopian, but which is coming. For this reason, art contributes to its advent. For the later Adorno, art is what assists decidedly the demonstration of all polar tensions; it is the embodiment of what in other contexts was called dialectic, the representative of what in all of philosophy appears stubbornly under the emblem of determined negation. ${ }^{60}$

We said previously that Lyotard, reflecting the environment of the postmodern megalopolis, sees the conflict of art with society, but he connects it with the desire as a longing for the impossible. Setting himself apart from the great narratives of modernism and from the tradition of metaphysics, especially from the Marxist tradition, but not from the attempt at differentiation in relation to the increasing homogeneity of linguistic and, as a result, social expressions, he suggests, as beneficial for thought, the generalization of the use of the meaning "resistance," where before there has been discussion about revolution, since he finds the meaning of "revolution" to be obsolete. ${ }^{61}$ The meaning, indeed, of "resistance" is formed by him in an aesthetic fashion, as has been said many times. ${ }^{62}$ Resistance to what, however, and why? Lyotard does not attribute, in contrast to Marxism, any extra-aesthetic character to art. ${ }^{63}$ Starting from the autonomy of the artwork, he attempts to consider the resistant nature of art through structural analysis. He will insist, indeed, that in order to be able to display the features of modern thought, we will have to apply a critical analysis of the aesthetic experience itself. $^{64}$ 
This analysis will show us that, if modern art has a basic feature, that is its invincible tendency to call itself into question; that is, its tendency to pose and to display its multiple and varied abilities, but also to undermine the idea of a work and the meaning of its form; in other words, to undermine an aesthetic that is oriented toward beauty. Modern art can make possible an aesthetic which turns toward the sublime and is founded on such an aesthetic. Then, where the aesthetic of beauty glorifies the agreement, the harmony of conflicts and the entirety, the aesthetic of the sublime, which is relevant to the unconventionality of the directions and the heterogeneity of the tendencies of contemporary art, the deep asymmetry, it is responsible for understanding the spoken word, according to which after every formation there remains, in a substantive way, some remnant which is unspeakable and excluded.

Let us note, however, here that this ontological composition of art does not render it the representative of conflict, of differentiation, and, ultimately, of dispersion. On the contrary, art, according to Lyotard, undertakes the very serious pedagogical obligation to function as a model, at the base of its form, of social inclusion and unity of varying orientations and choices of individuals. As such, art, according to Lyotard, functioning as the oriental star of a sublime politics, can display that what is sought in contemporary multicultural societies is the recognition of difference and, thus, of otherness and the relevant proof of wrong relationships of dominance.

Lyotard appeals to Kant, in order to bolster his opinion about the character of the sublime in contemporary art, with the sole difference, however, that Kant is cautious with the sublime, since in his time it did not express an art that resisted the violence of authority, but depicted its majesty. ${ }^{65}$ Thus, the idea of a practical Reason with ecumenical assertions does not appear to be at all familiar to Lyotard's work. But even to Adorno, Lyotard will see that the sublime takes in his aesthetic theory a position analogous with his own. Nevertheless, Adorno will not see the application of the predicate of the sublime only in artistic innovation but in every "authentic" work of art. In addition, while he recognizes the importance of the Kantian perspective on the understanding of the significance of the sublime, he will insist, in contrast to Lyotard, that the Kantian model needs critique, whereas we must proceed to a compositional change of the structure of the sublime. ${ }^{66}$ Since, indeed, its weakening would signify immediately that we transfuse to art the ideological recognition of the existing social condition, a totally new approach to the sublime through the criticism of the reappropriation of Kant's Analytic of the sublime is essential.

Despite the fact that Adorno considers that what bequeaths to us the sublime is none other than "harsh negativity," he finds that this in the first place is expressed primarily in the Kantian meaning of the powerfully sublime; that is, in this region in which the spirit resists the superiority of nature. ${ }^{67}$ In this way, he transfuses to the sublime, first of all, a primarily ethical dimension. The resistance of the spirit to nature as control over its indomitable character which has ceased of course to frighten us on account of the efficiency of both modern science and of technology, takes place, as we know, in the Kantian domain of composition of conflicting power and weakness. In this domain, Kant, according to Adorno, accepts the cooperation of the sublime with domination and a general will of submission; and that despite the fact that Kant submits to indirect criticism heroic classicism, from which springs an emphatic art. From exactly this event Kant states hesitant judgments on the possibility of an art of the sublime, with which Adorno agrees. This, however, does not distance Adorno from his obligation to exercise criticism on Kant, since he considers that the Kantian sublime comprises the aesthetic version of the Cartesian project which demands the self-establishment of the subject and the subjugation of nature, the aesthetic-pedagogical, that is, version of self-confirmation of the subject of neotericism, through which the instrumental-suppressive speech overpowers the fear that omnipotent nature produces. ${ }^{68}$ 
However, there is no doubt that Adorno's criticism, even if it does not clearly distinguish the criticism of the Kantian sublime from its metaphysical and ethical intake, is nevertheless essential to us to the degree that it insists, if only indirectly, in the substitution of the dominant metaphysical interpretation of the sublime, as begun by Schiller, developed with idealism, and consolidated under romanticism, with an approach which will consider the sublime as that experience which will show the subject its limits, which will recognize its irreducible differences from the emotion of beauty, and will allow for its differentiation from the ethical emotion of respect. ${ }^{69}$ In conclusion, in every attempt of undifferentiated identification of the aesthetic with the ethical, Adorno insists that we must protect the aesthetic texture of the sublime, remembering that the judgment of the sublime is an aesthetic judgment, which, if it does not want to be confused with teleological judgment or judgment of Reason, should not have any aim of object as qualifying principle. He stresses, indeed, as we have said, that the composition of the sublime must change, so that the application of a critical theory of the sublime may be possible in the analysis of the authentic work of art of modernity.

Adorno will ultimately resort to the forgotten epoch of the category of the sublime, because he considers that the sublime is the only possible place for art. In contrast to what the postmodern venture will later demonstrate, he refuses to connect in his thinking the sublime with the surge of the modern project as a whole. What primarily characterizes him is the recognition that he can understand an autonomous work of art who conceives of it through its negative relationship towards what is not art. As such, then, the aesthetic difference, the distinction between aestheticism and non-aestheticism, has, substantively, the character of an aesthetic negativity. To understand the work of art in terms of what it is, we cannot use signifiers such as difference, complement, coexistence. The unique nature of art does not have any relationship with its subordination to aims external to itself. Aesthetic autonomy is associated with the negativity of the artwork, its resistance, its opposition to a society, which is transformed into a blind society, as long as it yields to its desire to merchandise everything, transfusing a fetishistic character onto it; thus it makes everything into exchangeable products and enlarges a greedy Ego, translating it into a society of utter domination. ${ }^{70}$ As long as opposition to the social condition which is registered in the structure of the artwork, then aesthetic theory must distance itself from the conciliatory logic of beauty and must be bound by a sublime, with its inherently contradictory structure. And in contrast to Kant, who appears to be tentative about the idea of fine art, Adorno is positive about the generalization of the use of the category of the sublime, since it relates to the field of aesthetics as a whole and comprises the basic criterion for the degree of authenticity in the work of art.

Adorno will object to the Kantian designation of the paradigmatic dual meaning of the emotion of the sublime, inspired by the Nietzschean criticism in metaphysics that the duality of meaning must be disconnected from the sublime by the severe distinction between the experiential and the conceived Ego. Demonstrating, at the same time, solidarity with metaphysics at the moment of its destruction, he does not shrink from this particular distinction, but he alters it. The philosopher will insist that the aesthetic experience of the sublime comprises the central road of the formation of a relationship with the Absolute, which for the sake of the Absolute stands in the way of its every thematic definition. He will deny, then, the Kantian identification of the Absolute with practical reason and he will identify it with a radically indefinable horizon. Such an absolute is not of course the Kantian one, which even if not susceptible to representation is conceivable, but rather is substantively inconceivable. Such an absolute is covered with a black veil. ${ }^{71}$

Adorno's turn towards the sublime is associated entirely with the criticism that he applies to the sublime that it is metaphysically structured. Adorno finds fault with those who engage with high themes, dignifying 
them with an importance based on ideological criteria or respecting power and majesty. ${ }^{72} \mathrm{He}$ denies that the importance of art is knitted together with the actual or apparent value of represented objects, because in this case form is confounded with content. The sublime roots into the law that governs the form of a work of art. It does not refer to supposed important themes. ${ }^{73}$

Adorno attempts to set himself apart from the heroic approach to the sublime, claiming that, exactly through the experience of the sublime, the spirit realizes its naturalness. For that reason, the art of the sublime is transformed into what it is in itself, into the historical advocate of a repressed nature, which turns ultimately critically against the principle of the Ego, of the internal conveyor of repression. ${ }^{74}$ The authentic content of the sublime is proven through the experience of the naturalness of man. The experience of the sublime must be disconnected from the web of power, strength, and oppression of nature and to be seen as an experience of participation in nature and of common liberty with it. Here dominance is substituted by a participatory mimesis, while the experience of nature destroys the arrogance of the self determination of the subject.

Taking into consideration the Kantian position that the sublime is primarily emotion, Adorno will adjust the category of the sublime, interpreting it as what establishes a community between the subject and nature and gives a jumping off place to the spirit to reflect on its own essence. ${ }^{75}$ The subject, uncovering his naturalness, ceases to oppress nature and reconciles with it. ${ }^{76}$ Nature is liberated from the relationship of self-begotten development with the assertion of the subject for dominance. The experience of the sublime frees the subject from the principle of self-imposed subjectivity; it liberates him from the constant desire for power and from his involvement in aspirations for blind dominance. The subject, thus, is liberated from the principle of the Ego which aspires toward dominance over nature. The experience of the sublime forces the subject to set aside his dominant aspirations; to cut himself off from his demands for omnipotence, a fact that causes him to experience pain. Nevertheless, this pain is reformed in the promise of happiness, in the fulfillment of nostalgia for whatever has been cut off from the dense sphere of the Ego. ${ }^{77}$ Thus, the magical power brought to bear by the subject on nature, and into which he himself is caged, is cancelled out. Freedom, then, is not found in the disconnecting of the conceived Ego from its experiential essence, but in the consciousness of the subject for his likeness to nature.

In contrast to Adorno, Lyotard claims that what provokes the emotion of the sublime has no logic, as long as libido and the charge which supports it and which gives it essence exist only in dreams, if these are imprinted in words or if they are translated into phrases, which give the impetus for ramblings and the happenings that the writer, poet, or philosopher of the postmodern situation invents.

The sublime, as Adorno understands it, that is, as a basic characteristic of modern art as a whole, is beauty itself. Beauty is substantively the pseudonym of the sublime. Let us beware, however, here that the truth of the sublime, which is more closely connected with the law of form of artwork and not with its content, is in a position to carry out an advisory-paideutic function, because it is in an "erring condition." And, exactly because it is connected with the law of form, the sublime must always be in this condition. Modern art as art of the erring sublime "must turn against whatever comprises its self-same meaning;" otherwise it will fall, according to the philosopher, into the condition of the execution of an ideological function. Its meaning demands from it to place an entirety, something closed in itself. The creation of such a formic entirety is necessary for the preservation of its autonomy. This closed nature however functions as affirmative of an erring society. With art remaining in its autonomy, it leaves society untouched, and thus in essence it approves it. It must, then, stand in contrast to its autonomous self, and rupture the relationship between autonomy and affirmation. This 
relationship must arrive at its extreme boundaries, if art wants to rupture it: The work, shaped according to its own extant law and as a unit, is in a position, in its silence, to criticize a society that has fallen down into the principle of exchange, where everything applies through its reference to something else and not to itself. This exactly is the "uncharitable negativity" of art. The possibility of rupture of the relationship is written into the structure of the sublime, since the comprising lines of society, based on the authority of nature, are shaken. The subject, acquiring an understanding of his naturalness, is freed from the mad desire for authority.

The difference of the constructive and of the mimetic in art, indivisible in essence for every work of art, is what requires it to be in conflict with its meaning. This internal composition of art, which crystallizes in the completed artwork, renders the work a testament of dominance. The unification of ingredient parts in a cohesive whole, in the form that presupposes the violent embodiment of that which deviates, leads the artwork to the composition of a structure of dominance. As such, the entire beauty includes the element of violence as an indissoluble element of beauty.

According to the German philosopher, then, the fullest autonomy of the artwork leads to its fuller organization in the principle of dominance. But what we must beware is that Adorno is not exhausted by the demand that one leaves off from dominance. The issue is for art to express the variance and not to liberate the manifold from abstract opposition to unity. In any case, this liberation could not express the variance. The aim of art, the philosopher will write, is "the salvation of the many through the one."

Let us note, now, that according to Adorno, dominance and its subversion in artwork are perpetually connected in a paradoxical way. And in the final analysis, art is not completed with composition but with fragmentation. Indeed, it is fragmented with the same strength with which its composition was earlier created. The fact of the attempt at unification of the spirit with the material belongs to the experience of the sublime, which results in none other than the furthering of the one from the other. This opposition of art to its meaning has, as its aim, the restoration of an oppressed and historically trapped nature. Art wants to correct what the spirit, the thought, perpetrates on the other, as art. The sublime propels the work of art into something that is no longer suited to the meaning of the work: "works over which the aesthetic form self-surpasses", writes the German philosopher, "assume the position that at some other time the meaning of the sublime held" (351-3). ${ }^{78}$ Thus, modern art is called upon to embody the structure of the sublime.

At the level of rational and thematic analysis, Adorno conceives of the work of art as a form of reconciliation. Processing, however, of this conception at the basis of the experience of the sublime leads him to its radical alteration. Even if he does not stop talking about a successful work of art, he considers that this success would be a thoroughgoing composition which would have rendered the artwork a pointless work. The fine composition would require the manifold to appear as its element and would transform the work into the opposite of what it desired to be; in other words, a manifestation of dominance. The artwork must seek after unity, because without this unity, variance from trends cannot appear. And this variance, which is its paradox, must be endured by the artwork. A full unity would lead to the disappearance of the paradox, of the contradiction.

The recognition, however, of discordant trends precedes hope for reconciliation. There is no possibility for the reconciliation of contradictions. This position is surely normative, but at the same time it provides a descriptive dimension. In today's social condition, reconciliation is "radically unattainable." because reconciliation is unattainable, Adorno is propelled to claim that the idea of reconciliation must be replaced by a demand for the salvation of the many through the one. Now the nebulous ideal of reconciliation 
will give way to the hard and sober meaning of justice, since Adorno understands that the heterogeneous neutralizes the possibility of a final unity and reconciliation. Aesthetic unity must allow "the rendering of justice to the heterogeneous," Adorno will say. This failure of the ideal is explained, of course, aesthetically. It is not owed so much to increased dominance "of the relationship of blindness" as to the compositionally irreconcilable character of the work of art, in the sense that its structural elements, as substantively discordant, resist every attempt of classification into a fine whole. ${ }^{80}$

After all, we have said so far that it is clear that the experience of the sublime, as it has been analyzed in the context of Adorno's aesthetic theory, has in fact an excellent paideutic value and could function positively in the context of an aesthetic education, as a vanguard of self-consciousness. The great question, of course, which comes up here, is if today, art itself is strong and, if so, if it can display its negative character.

Despite the fact that when the postmodern period began, in the 1970s, very few, such as Castoriadis in France or Harold Rosenberg in the United States, ${ }^{81}$ believed that cultural creativity in the west had been fully weakened, in recent years most consider this obvious, there is no longer any doubt that we in the western world are living in such a period. ${ }^{82}$ Having decided to dominate nature, we have passed into the dominance of man and we have set ourselves up, through the desire for a generalized mastery, for the bottomless desire for the merchandization of all things, where the relationships between people have been transformed into relationships between things. ${ }^{83}$ In such a context, art has not only lost its negative character but is so weakened that some speak even of its death.

This, however, does not stop some, even under the current conditions, from trying to convince unrepentant devotees that art was never an element of social cohesion or improvement, and that the comedy of Fine art should be blamed, as long as a procedure of cultural democratization takes place in the western world through the non-homogeneity of cultural groups and, thus, the forms of art continue to develop in the bosoms of active communities. Yves Michaud, indeed, urges us to accept the end of the utopia of art without sentimentalism and to see that the idea of a Fine aesthetic for a Fine art was a terroristic mechanism that had as its goal the negation of the diversity of artistic behaviors. ${ }^{84}$ But if the situation is thus, one must wonder how today the social bond can be ensured, given that this bond between groups and communities is essential. And, furthermore, how all this will contribute to the insurance of fertile diversity.

What Michaud forgets is that works of art have as creations a collective dimension, either in their making or in their reception, but they comprise, as well, the ballast of a collective identity. Works of art comprise a bond between the past and the future of a society; they comprise an inexhaustible memory bank and, at the same time, a support of future creation. With his position, Michaud states that in contemporary society, in the context of democratic individualism, there is no longer any room for great works. Thus, it is as if he has unwillingly published a death sentence for society. We could indeed add that whosoever compromises too easily with the idea that the great work of art has departed as an impossibility, appears to have permanently given up and wishes to convince others that they too must permanently give up from the need to give a new form to beauty.

It is true that we live in a time that is fed entirely by repetition, since there is a collapse of the present that burdens both the past and the future with debt. The relationship indeed between the western world and its own past is lived out with the most radical exotericism. Let us imagine that this situation becomes even more serious, given that the problem of the relationship with culture in general comprises a problem of the relationship with values, that is, with what a society desires and with what holds it together. Relevant to this, it comprises a 
socialization methods problem. Are there, however, we may ask, such values in this world as forms of education and civilized life, as socio-historical type of individuals, as the meaning of the relationship of collectivity with itself? Are there, in other words, values that strongly declare their presence? And here, it is clear that, through this viewpoint the problem of art, touches upon the political problem. If a work of art, then, provokes an objection, how can we consider this objection if not as the calling into question of an established thought? And would this questioning be possible without the thought being a well founded one? Would it be possible, if the values did not declare their presence strongly?

Even a quick glance at our world convinces us that the values that underpin it today not only are not governed by strong presence and do not promote collectivity, but essentially promote fragmentation and dissipation. ${ }^{85}$ When the entire west is oriented towards the values of the possession of wealth, brand, and power, how could the spirit of collectivity be awakened? In contemporary western societies, all human activities and all their consequences end up being considered better or worse, characterized and valued on their economic dimension, everything converted into merchandise. ${ }^{86}$ With the economy set up in the center of public and private life, it neutralizes anything that does not have an instrumental or functional character and is not governed by an effectiveness that continues to deify the ideology of progress that begat our modernity. The prevalence of instrumental rationality and technoscience, on which this ideology is founded, in order for the spirit of calculation and profit that mercilessly ravages our humanity to be generalized, establishes conditions of control and allows the spread of dominance in all areas. The generalization of political apathy and the move towards private life both of individuals and of nations, which transforms the world into an ever growing desert, propels the democratic ethos, which is to say responsibility, reverence, outspokenness, mutual control and awakened consciousness that recognizes how what relates to common matters, relates to each person individually, to retreat. ${ }^{87}$ The associated weakening of political imagination accompanies the destruction of public space and public time for thought, while the destruction both of learned and popular tradition is hastened. And while irrationality grows and leads us to the destruction of our earthly environment for development for development's sake, the last vestiges of Aristotelian phronesis for the paideutic context of western societies are extinguished.

In these conditions of a permanent crisis of democracy, the activation of the experience of the sublime through art could set in motion, in connection with other redemptive moves in various areas of private and public life, the obviation of these weaknesses, to the degree to which it would show man that the world in which he can live is not necessarily the existing one, and that he must de-establish himself from such a hubristic social context, rupturing the delusion of his omnipotence, in order to stop his slipping swiftly into his own destruction. In avoiding such a dreadful future, we believe that art can play a fundamental role, especially working on the motif of the sublime. If, indeed, societies reignite their liberating experience through aesthetic education, human beings will be able to turn away from all those things that gestate their destruction, while they will see to their own humanization continuously and in every possible way. We consider that the attempt of all modern art to render the absolute registers the attempt of human beings to avoid hubris with phronesis, as far as is possible, to create a world that deserves to be lived in. And this is exactly what Adorno attempts in his aesthetic theory, aligning himself, in the final analysis, with the demand for the demonstration of the ideal of justice. 


\section{Notes}

1. Cornelius Castoriadis. Fenêtre sur le chaos. Paris: Seuil, 2007.

2. In total separation from the aesthetic orientation of the Frankfurt School, devaluing, in other words, every footing of art from society, the representatives of the aestheticism movement considered that nothing else had meaning in the world aside from art and beauty. An absolute and unique ideal of life in this vein can be none other than beauty, the worship of beauty, the cultivation of beauty. Cf. the classic, Robert Vincent Johnson. Aestheticism. London: Methuen, 1969. It is good to add in relation to this Adorno's observation that even hermetic art, due to its antisocial character, embodies, barely, social criticism.

3. Theodor W. Adorno. Aesthetic Theory. Trans. R. Hullot-Kentor. London \& New York: Continuum, 2002, passim. Cf. Jean Clair. La responsabilité de l'artiste. Paris: Gallimard, 1997.

4. Theodor W. Adorno. Aesthetic Theory. Passim and Prismes. Critique de la culture et de la société. Trad. J. Rochlitz and R. Rochlitz. Paris: Payot, 1986.

5. Cf. Présences d'Adorno. Collectif. Paris: U.G.E., 1975.

6. Theodor W. Adorno. Aesthetic Theory. 86-87; 113-4. Cf. Marc Jimenez. Adorno et la modernité. Vers une esthétique negative. Paris: Clincksieck, 1984.

7. Cf. Marc Jimenez. Qu'est-ce que l'esthétique? Paris: Gallimard.

8. The generalization of commercialization is absolute. Today, as it has been established in the fields of scientific and artistic production, it penetrates deeply even into the field of philosophical query. Indeed the mechanisms which eased the commercialization of culture attempt simultaneously to trivialize its great creators.

9. Martin Heidegger. The Origin of the Work of Art (I proeleusi tou ergou technis). Athens: Dodoni, 1986.

10. See the last sentence of the Epilogue of the text of Walter Benjamin, "The Work of Art in the Age of Mechanical Production, in On Artwork (Gia to ergo technis). Trans. A. Oikonomou. Athens: Plethron, 2013, 87. Also, Rainer, Rochlitz. The Disenchantment of Art. The Philosophy of Walter Benjamin. Trans. J. M. Todd. New York: Guilford Press, 1996.

11. Arts et pouvoirs. Dir. Paris: Klincksieck, 2007.

12. Heidegger, Adorno, and Merleau-Ponty all resisted, among other things, the dominant positivism of art criticism and the theory of art in the twentieth century.

13. Heidegger writes: "Whenever art happens, that is, whenever there is a jumping-off point, a push is given to history, history commences or restarts." Art is, according to Heidegger, historical, because thanks to it, the truth is promoted as non-concealing, because initially truth happens. And this event is what lays the foundation of history. Martin Heidegger. The Origin of the Work of Art (I proeleusi tou ergou technis). 130.

14. The burden on aesthetics with such duties stems, of course, from the tradition of Germanic idealism and especially from Kant, Schiller, and Schelling.

15. It is often noted that Lukács remained attached to the classical criterion, which barred him from seeing what was at stake in 20th century art. See indicatively, Georg Lukács. La théorie du roman. Trad. J. Clairevoye. Paris: Denoël, 1968. Lukács could not see the radical character of art.

16. In the entire Heideggerian opus, from the earliest to the latest works, the position of technology in the modern world and its relationship with its metaphysical weakening are set as a constant and intense query. Heidegger will connect it with technoscience and will feature it as a great threat to the world, to the extent that it requires devotion to beings and puts any distance between truth and man. See, in this regard, Martin Heidegger. Being and Time. Trans. J. Stambaugh. Albany: State University of New York Press, 1996. For Adorno, as well, the instrumental rationality which governs contemporary art, as representing the effectiveness which is connected with the acquisition of profit, is located in substance beyond the fact of art. Theodor W. Adorno. Aesthetic Theory. 56-60; 127-9.

17. Martin Heidegger. The Origin of the Work of Art. 128-32.

18. See, in this regard, Eva Geulen. The End of Art. Readings in a Rumour after Hegel. Trans. J. McFarland. Stanford: Stanford University Press, 2006. Also, Arthur Danto. Après la fin de l'art. Paris: Seuil, 1996.

19. Jean François Lyotard. "The Sublime and the Avant-Garde." Lyotard Reader. Oxford: Basil Blackwell, 1989, 211.

20. Jean François Lyotard. Economie libidinale. Paris: Minuit, 1974 and L'inhumain. Causeries sur le temps. Paris: Galilée, 1988.

21. Dominique Château. L'ésthetisation de l'art. Art contemporain et cinéma. Paris: Editions de l' Amandier, 2014, which provides additional bibliography.

22. As in Adorno, also in Benjamin and Marcuse the interest in happiness is especially great and makes up a central theoretical thrust. By contrast, in Habermas the approach to happiness is made formalistically, especially in an ethical context.

23. Theodor W. Adorno. Aesthetic Theory. 74-76; 352-6.

24. Georg Wilhelm Friedrich Hegel. Aesthetics. Lectures on Fine Art, Vol. 1, 2. Trans. T. M. Knox. Oxford: Clarendon Press, 1975.

25. Georg Wilhelm Friedrich Hegel. Aesthetics. Lectures on Fne Art. 2; 7; 8.

26. Georg Wilhelm Friedrich Hegel. Philosophy of Spirit (I filosofia tou pneumatos), Vol. I. Trans. G. Tzavaras. Athens: Dodoni, 1993.

27. Georg Wilhelm Friedrich Hegel. Aesthetics. Lectures on Fine Art. 4-5. Cf. the introduction to the translation in Hegel. Introduction to Aesthetics (Hegel. Eisagogi stin Aesthitiki). Trans. G. Veloudis. Athens: Polis. 
28. Georg Wilhelm Friedrich Hegel. Aesthetics. Lectures on Fine Art. 12-13. 1992.

29. Johann Christoph Friedrich von Schiller. Lettres sur l'éducation ésthetique de l'homme. Trad. R. Leroux. Paris: Aubier,

30. Georg Wilhelm Friedrich Hegel. Aesthetics. Lectures on Fine Art. 49.

31. This appears primarily in Kant.

32. Theodor W. Adorno. Aesthetic Theory. 4-7; 217-8; 252-5.

33. Theodor W. Adorno. Aesthetic Theory. 127-9; 345-50.

34. Theodor W. Adorno. Aesthetic Theory. 348-53.

35. Theodor W. Adorno. Aesthetic Theory. 583; 353-6 and Autour de la théorie esthétique. Paralipomena, Introduction première. Trad. M. Jimenez-E. Kaufholz. Paris: Clincksieck, 1976.

36. At the bottom of this conception is, of course, the Marxist position of the total connection between art and social reality.

37. Theodor W. Adorno. Aesthetic Theory. 236-7 and Introduction to the Sociology of Music. London: Continuum, 1988 and Philosophie de la nouvelle musique. Trad. H. Hildenbrand and A. Lindensberg. Paris: Gallimard, 1979.

38. Theodor W. Adorno. Aesthetic Theory. 583. 9-15. Immanuel Kant. Critique de la faculté de juger. Trad. A. Philonenko. Paris: Vrin, 1989. Cf. Sigmund Freud. Un souvenir d'enfance de Léonard de Vinci. Trad. M. Bonaparte. Paris: Gallimard, 1977 and The Moses of Michelangelo. Athens: Erasmus, 2010.

39. "Mimesis in art," writes the philosopher, "is something pre-spiritual and in contrast to the spirit; it is, however also the spark which lights the spirit. In artwork, the spirit becomes the beginning of their construction, but corresponds to their final result only when they arise through mimetic impulses, when the object of construction binds onto these tenderly and does not attempt to impose dominance on them. The form objectifies these individual impulses only when it follows them there where on their own they wish to go. This alone is the participation of the work of art in reconciliation. The rationality of works of art becomes spirit only when it disappears through its diametric opposite." Theodor W. Adorno. Aesthetic Theory. $131 \mathrm{ff}$.

40. Theodor W. Adorno. Aesthetic Theory. 45-49. Perhaps here we have an echo that can be heard in the Kantian Sublime.

41. Theodor W. Adorno. Aesthetic Theory. 61-78.

42. Cf. Herbert Schnadelbach. "Philosophy after Heidegger and Adorno." Leviathan, 8. 1990, 68-86.

43. Theodor W. Adorno. Aesthetic Theory. 34. To conclude, for Adorno, the defined character of art can surpass its natural counterpart. Nevertheless, art does not have its model in the spirit that men assign to it, but in the expression of nature. Theodor W. Adorno. Aesthetic Theory. 91-93 and Autour de la théorie esthétique.

44. The first discussion on this condition took place in philosophical anthropology in Dialectic of Enlightenment. Theodor W. Adorno and Max Horkheimer. Dialectic of Enlightenment. Trans. E. Jephcott. Stanford University Press, 2007. In approximately the same period as Adorno, Derrida wanted to show with passion the generalized polysemy that hides behind writing. Jacques Derrida. L'écriture et la difference. Paris: Seuil, 1967.

45. Theodor W. Adorno. Aesthetic Theory. 112-7.

46. Theodor W. Adorno. Aesthetic Theory. 113 ff. Cf. Maurice Merleau-Ponty. Le visible et l' invisible. Paris: Gallimard, 1979.

47. Theodor W. Adorno. Aesthetic Theory. 8-12.

48. Theodor W. Adorno. Introduction to the Sociology of Music.

49. Theodor W. Adorno. Aesthetic Theory. passim.

50. For a clarification on the relationship of the symbolic to the imaginary, as well as for the understanding of the constitution of the social world as a world of social imaginary meanings, cf. Cornelius Castoriadis. L'Institution imaginaire de la société. Paris: Seuil, 1975.

51. Theodor W. Adorno. Aesthetic Theory. 163-74.

52. Theodor W. Adorno. Aesthetic Theory.

53. Theodor W. Adorno. Aesthetic Theory.

54. The philosopher's position on this reminds of us fragment B 53 of Heraclitus: "War is the father of all

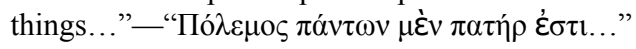

55. Martin Heidegger. The Origin of the Work of Art. 72.

56. According to Heidegger, the language of poetry is the archegonial language. The poet, however, does not write verses for each "today." He speaks the language of his own being, which already a long time since has been said to us in the speaking; it is unfolded widely before us and we have never seen it before. Consequently, poetic language is never present language, but always of the past and the future. A poet is never contemporary. Although contemporary poets are categorized in groups, this is an absurdity. True poetry and by extension language in itself take place only there where its dominance leads to the superior intact state of archegonial speech. Martin Heidegger. On the Way to Language. New York: Harper, 1982.

57. Martin, Heidegger. The Origin of the Work of Art. 123-5 and Being and Time. Also, Maurice Merleau-Ponty, Le visible et l'invisible.

58. Martin Heidegger. On the Way to Language.

59. Modern art, according to Adorno, and contrary to Lukács, did primarily this; it escaped from society through its cryptic character, through pain, and through its distortion of common, communicative language.

60. Theodor W. Adorno. Dialectique négative. Trans. J. Coffin et al. Paris: Payot, 1978.

61. Jean-François Lyotard. La condition postmoderne. Paris: Minuit, 1979.

62. Jean-François Lyotard. Economie libidinale and L'inhumain. Causeries sur le temps. 
63. On the topic of marxism, Georg, Lukács. La théorie du roman.

64. Of course, in Lyotard's attempt to connect modernity exclusively with art, he ignores the multiple and complex intermixtures of individual areas of culture. And this is not without consequence.

65. Jean-François Lyotard. L'inhumain. Causeries sur le temps. op. cit.

66. Theodor W. Adorno. Aesthetic Theory. 194-8.

67. Theodor W. Adorno. Aesthetic Theory. 160-5.

68. Adorno reminds us that, in this context, the majesty of man as spiritual being and as tamer of nature ought to be "sublime." Theodor W. Adorno. Aesthetic Theory. 160-5; 210.

69. According to Schiller, the experience of the sublime not only conforms to the expression of emotion of our destination as of ethical autonomous beings with our ability to become independent of our experiential predisposition, but it provokes us to the exercise and development of our autonomous will. Therefore, it acts pedagogically on our ethical action, since our aesthetic experience makes possible a free agency in our confrontation with the invincible force of nature. According to Schiller, man is a being of will and his liberty is founded on this will. He is transformed into a slave when he is obligated to act contrary to his will. If indeed he discovers that it is impossible to be opposed to the force of nature, then he must negate its violence as such and endure the consequences of its superiority. The interest is at the point where Schiller considers as a primarily ethical culture one which has educated human beings in such a way that they are always ready to adopt such a position. In the aesthetic texts, he will substantiate the sublime and at the same time will make it ethical to such a degree that gradually it will be assimilated into the field of ethics. His central concern, in any case, will prove to be the ideally beautiful composition through art not only of beauty and the sublime, but also of the sensuous and suprasensuous or of the finite and the infinite. Johann Christoph Friedrich von, Schiller. Nä̈ve and Sentimental Poetry and on the Sublime: Two Essays. Trans. J. A. Elias. New York: Frederick Ungar, 1966. See also the texts "On the art of tragedy," "On the pathetic," and "Concerning the sublime" in Essays: Friedrich Schiller. Eds. W. Hinderer \& D. O. Dahlstrom. Trans. Dahlstorm D. O., Wilkinson E. M. and Willoughby L. A. New York: Continuum, 1993 and Lettres sur l'éducation ésthetique de l'homme.

70. Theodor W. Adorno. Aesthetic Theory. 32-33; 340-1 and Prismes. Critique de la culture et de la société.

71. Theodor W. Adorno. Aesthetic Theory. 194-8.

72. Theodor W. Adorno. Aesthetic Theory. 118-9.

73. Theodor W. Adorno. Aesthetic Theory.

74. Theodor W. Adorno. Aesthetic Theory. 194-8.

75. Theodor W. Adorno. Aesthetic Theory. 225-61.

76. Theodor W. Adorno. Aesthetic Theory.

77. Adorno here refers to a psychoanalytical condition, one which understands the composition of the psychic sphere on the level of anthropopoeisis as that which recognizes itself as omnipotent, from which emerges the constant need of the subject to dominate. One of these expressions of dominance is the generalization of the use and imposition of instrumental logic. Withdrawing the subject from his aspirations for dominance, he enters the area of pain. This pain will be transformed into the promise of happiness, when the subject recognizes that he can be happy, fulfilling his nostalgia for all those things that were excluded from the dense sphere of the Ego. Here, however, we find a difficulty of anthropological nature: In the composition of the subject, there is no situation other than the situation of full demand for omnipotence. See in relation, Sigmund Freud. Civilization and Its Discontents (O politismos pigi dystychias). Trans. G. Bambalis. Athens: Epicurus, 1994.

78. Theodor W. Adorno. Aesthetic Theory. 351-3.

79. Theodor W. Adorno. Aesthetic Theory. 250-61 and Autour de la théorie esthétique.

80. Theodor W. Adorno. Aesthetic Theory.

81. Cf. the text "Social Transformation and Cultural Creation" in Cornelius, Castoriadis. Fenêtre sur le chaos. In the USA already by 1972, Harold Rosenberg was counted among the few who were concerned with the value of artistic production in the western world. See his excellent work Harold Rosenberg. The De-definition of Art. New York: Macmillan, 1972.

82. No one could doubt that in the art of the 70 s and afterwards we find recycling of disparate and degenerate fragments. And however tentative we may be, it would be impossible for us to claim that the last decades have seen the kind of morphological revolution that typified the first thirty years of the twentieth century.

83. Debord insists, and very rightly, already in the $60 \mathrm{~s}$, that these relationships have been transformed into relationships between images. Guy Debord. La société du spectacle. Paris: Gallimard, 1996.

84. Yves Michaud. La crise de l' art contemporain. Paris: PUF, 1997. Cf. Philippe Dagen. La haine de l'art. Paris: Grasset, 1997.

85. Cf. Cornelius Castoriadis. Le monde morcelé. Les carrefours du labyrinthe III. Paris: Seuil, 1990.

86. G. Lukács will attempt in his work History and Class Consciousness important analyses on the reification of the entirety of social life produced by capitalism.

87. Cf. Cornelius Castoriadis. Domaines de l'homme. Les carrefours du labyrinthe, II. Paris: Seuil, 1986 and La Montée de l' insignifiance. Les carrefours du labyrinthe, IV. Paris: Seuil, 1996.

\section{Works Cited}

Adorno, Theodor W. Aesthetic Theory (Aesthitiki Theoria). Athens: Alexandreia, 2000. 
---. Aesthetic Theory. Trans. R. Hullot-Kentor. London \& New York: Continuum, 2002.

---. Dialectique négative (Negative Dialectics). Trans. J. Coffin et al. Paris: Payot, 1978.

---. Autour de la théorie esthétique (On Aesthetic Theory). Paralipomena, Introduction première. Trad. M. Jimenez-E. Kaufholz. Paris: Clincksieck, 1976.

---. Philosophie de la nouvelle musique (Philosophy of Modern Music). Trad. H. Hildenbrand and A. Lindensberg. Paris: Gallimard, 1979.

---. Prismes. Critique de la culture et de la société (Prisms. Cultural Criticism and Society). Trad. J. Rochlitz and R. Rochlitz. Paris: Payot, 1986.

---. Introduction to the Sociology of Music. London: Continuum, 1988.

Adorno, Theodor W. and Horkheimer, Max. Dialectic of Enlightenment. Trans. E. Jephcott. Stanford Universtity Press, 2007.

Benjamin, Walter. On Artwork (Gia to ergo technis). Trans. A. Oikonomou. Athens: Plethron, 2013.

Castoriadis, Cornelius. Fenetre sur le chaos (Window on the Chaos). Paris: Seuil, 2007.

---. L'Institution imaginaire de la société (The Imaginary Institution of Society). Paris: Seuil, 1975.

---. Domaines de l'homme. Les carrefours du labirynthe, II (Domains of Man. The Crossroads in the Labyrinth II). Paris: Seuil, 1986.

---. La Montée de l'insignifiance. Les carrefours du labyrinthe, IV (The Rise of Insignificance. The Crossroads in the Labyrinth IV). Paris: Seuil, 1996.

---. Le monde morcelé. Les carrefours du labyrinthe III (The Fragmented World. The Crossroads in the Labyrinth III). Paris: Seuil, 1990.

Chateau, Dominique, L'ésthetisation de l'art. Art contemporain et cinéma (The Aestheticization of Art. Contemporary Art and Film. Paris: Editions de l' Amandier, 2014.

Clair, Jean. La responsabilité de l'artiste (The Responsibility of the Artist). Paris: Gallimard, 1997.

Dagen, Philippe. La haine de l'art (The Hatred of Art). Paris: Grasset, 1997.

Danto, Arthur. Après la fin de l'art (After the End of Art). Paris: Seuil, 1996.

Debord, Guy. La société du spectacle (Society of the Spectacle). Paris: Gallimard, 1996.

Derrida, Jacques. L'écriture et la difference (Writing and Difference). Paris: Seuil, 1967.

Essays: Friedrich Schiller. Eds. W. Hinderer and D. O. Dahlstrom. Trans. Dahlstorm D. O., Wilkinson E. M. and Willoughby L. A. New York: Continuum, 1993.

Freud, Sigmund. Un souvenir d'enfance de Léonard de Vinci (Leonardo da Vinci and a Memory of His Childhood). Trad. M. Bonaparte. Paris: Gallimard, 1977.

---. The Moses of Michelangelo (O Moises tou Michail Aggelou). Athens: Erasmus, 2010.

---. Civilization and Its Discontents (O politismos pigi dystychias). Trans. G. Bambalis. Athens: Epicurus, 1994.

Geulen, Eva. The End of Art. Readings in a Rumour after Hegel. Trans. J. McFarland. Stanford: Stanford University Press, 2006. Hegel, Georg Wilhelm Friedrich. Aesthetics. Lectures on Fine Art, Vol. 1, 2. Trans. T. M. Knox. Oxford: Clarendon Press, 1975.

---. Hegel. Introduction to Aesthetics (Hegel. Eisagogi stin Aesthitiki). Trans. G. Veloudis. Athens: Polis, 2000.

---. Philosophy of Spirit (I filosofia tou pneumatos), Vol. I. Trans. G. Tzavaras. Athens: Dodoni, 1993.

Heidegger, Martin. The Origin of the Work of Art (I proeleusi tou ergou technis). Athens: Dodoni, 1986.

---. Being and Time. Trans. J. Stambaugh. Albany: State University of New York Press, 1996.

---. On the Way to Language. New York: Harper, 1982.

Jimenez, Marc. Qu'est-ce que l' esthétique (What Is Aesthetics)? Paris: Gallimard, 1997.

---. Adorno et la modernité. Vers une esthétique negative (Adorno and Modernity. Towards a Negative Aesthetic). Paris: Clincksieck, 1984.

---. Arts et pouvoirs (Arts and Authority). Dir. Paris: Klincksieck, 2007.

Johnson, Robert Vincent. Aestheticism. London: Methuen, 1969.

Kant, Immanuel. Critique de la faculté de juger (Critique of Judgment). Trad. A. Philonenko. Paris: Vrin, 1989.

Lukács, Georg. La théorie du roman (The Theory of the Novel). Trad. J. Clairevoye. Paris: Denoël, 1968.

Lyotard, Jean-François. La condition postmoderne (The Postmodern Condition). Paris: Minuit, 1979.

---. Economie libidinale (Libidinal Economy). Paris: Minuit, 1974.

---. L'inhumain. Causeries sur le temps (The Inhuman. Causeries on Time). Paris: Galilée, 1988.

Lyotard Reader. Oxford: Basil Blackwell, 1989. 211.

Merleau-Ponty, Maurice. Le visible et l'invisible (The Visible and the Invisible). Paris: Gallimard, 1979. 
Michaud, Yves. La crise de l'art contemporain (The Crisis of Contemporary Art). Paris: PUF, 1997.

Présences d'Adorno. (Collectif). Paris: U.G.E., 1975.

Rochlitz, Rainer. The Disenchantment of Art. The Philosophy of Walter Benjamin. Trans. J. M. Todd. New York: Guilford Press, 1996.

Rosenberg, Harold. The De-definition of Art. New York: Macmillan, 1972.

Schiller, Johann Christoph Friedrich von. Lettres sur l'éducation ésthetique de l' homme (On the Aesthetic Education of Man). Trad. R. Leroux. Paris: Aubier, 1992.

---. Naïve and Sentimental Poetry and on the Sublime: Two Essays. Trans. J. A. Elias. New York: Frederick Ungar, 1966. 